
МУЗИКОТЕРАПІЯ У КОРЕКЦІЇ ПОВЕДІНКОВИХ ПОРУШЕНЬ ДОШКІЛЬНИКІВ
ІЗ РОЗЛАДАМИ АУТИСТИЧНОГО СПЕКТРУ

\title{
MUSIC THERAPY IN THE CORRECTION OF BEHAVIORAL DISORDERS OF PRESCHOOLERS WITH AUTIC SPECT DISORDERS
}

\begin{abstract}
Стаття присвячена вивченню проблеми корекції поведінкових порушень у дітей дошкільного віку з аутистичними проявами в умовах закладів дошкільної освіти. Звернено увагу на аналіз досліджень з окресленої проблеми, зокрема з питань музикотерапії, яка $є$ одним з методів впливу на поведінку особистості. Зазначено, що вагомі доробки у цьому напряму є у зарубіжних учених. Охарактеризовано особливості розвитку дітей 3 аутизмом, серед яких є нецілеспрямована рухова активність, яка виявляється в стрибках, своєрідних рухах пальців рук біля зовнішніх кутів очей, рухова активність може чергуватися з періодами загальмованості, завмирання в одній позі.
\end{abstract}

Ґрунтуючись на аналізі літературних джерел, наголошено, що музика посилює обмін речовин, посилює або зменшує м'язову енергію, змінює дихання, змінює кров'яний тиск, дає фрізичну основу для емочій. Зазначено, що для того щоб музикотерапія позитивно вплинула на поведінку дошкільників з аутизмом, необхідно враховувати особливості dimeй. Окреслено напрями музикотерапії у роботі з дітьми дошкільного віку з аутиз мом: вокалотерапія (співи), музикотерапія в рухах (танці, музично-ритмічні ігри), музикування на музичних інструментах

Визначено вплив музики на настрій та поведінку дітей. Наведено музичні твори, які застосовуються у практичній корекційно розвивальній роботі з дітьми з розладами аутистичного спектру. Зазначено, що корисним є застосування у музичній терапії різних творів: дитячої музики, дитячих пісень, української народної музики та пісні, класичної музики.

Наголошено, що музика може бути провідним методом корекції поведінкових порушень у дошкільників з розладами аутистичного спектру лише в тому випадку, коли музичний вплив є системним і різноплановим.

Описано практичний досвід застосування музикотерапії роботи з дошкільниками 3 аутизмом у дошкільному закладі, а саме обгрунтовано та подано добір музичних творів, які використовуються у корекційнорозвитковій роботі: твори, які сприяють зниженню агресивних проявів, викликають добрі почуття, стимулюють тактильний сенсорний розвиток, пізнавальну активHicmb.

Ключові слова: діти, дошкільники, аутизм, розлади аутистичного спектру, поведінка, порушення, музика, музична терапія.
The article is devoted to the study of the problem of correction of behavioral disorders of preschool children with autistic manifestations in terms of preschool education institutions. Attention is paid to the analysis of research on the outlined problem, in particular on music therapy, which is one of the methods of influencing on the behavior of the individual. It is noted that foreign scientists have significant achievements in this direction. Features of children's development with autism are characterized, among which there is unfocused motor activity which is shown in jumps, original movements of fingers near external corners of eyes, motor activity can alternate with the periods of inhibition or fading in one pose.

Based on the analysis of literature sources, it is emphasized that music increases metabolism, increases or decreases muscle energy, changes respiration, changes blood pressure, provides a physical basis for emotions. It is noted that for music therapy to effect positively on the behavior of preschoolers with autism, it is necessary to take into account the characteristics of children. The directions of music therapy in work with preschool children with autism are outlined: vocal therapy (singing), music therapy by means of movements (dances, musicalrhythmic games), making music on musical instruments.

The influence of music on the mood and behavior of children is determined. There are given musical works that are used in practical corrective and developmental work with children with autism spectrum disorders. It is noted that it is useful to use various works in music therapy: children's music, children's songs, Ukrainian folk music and song, classical music.

It is noted that music can be the leading method of correcting behavioral disorders in preschoolers with autism spectrum disorders only in the topic of the case when the musical influence is systemic and diverse.

The practical experience of using music therapy to work with preschoolers with autism in preschool is described. Namely the selection of musical works used in correctional and developmental work is substantiated and presented: pieces that help to reduce aggressive manifestations, cause good feelings, stimulate tactile sensory development and cognition.

Key words: children, preschoolers, autism, autism spectrum disorders, behavior, disorders, music, music therapy.
Постановка проблеми у загальному вигляді. Розвиток суспільства, його трансформаційні зміни передбачають роботу щодо соціалізації й адаптації осіб з особливими освітніми потребами, зокрема дітей з розладами аутистичного спектру, чисельність яких збільшується щорічно. Відомо, що для дітей з розладами аутистичного спектру характерними є складнощі спілкування та само- контроль поведінкових реакцій, що надалі ускладнює їх інтегрування у суспільство, інклюзивну освіту. Отже, постає питання пошуку ефективних методів корекційно-розвиткової роботи з такими дітьми, серед яких важливе місце посідає музикотерапія.

Аналіз останніх досліджень і публікацій. Вивченням організації корекційно-розвивальної 
роботи з дітьми з розладами аутистичного спектру розвитку вивчається протягом останніх десятиліть досить інтенсивно (О. Аршатська, О. Баєнська, В. Башина, М. Веденіна, К. Лебединська, І. Мамайчук, О. Нікольська, К. Островська, Д. Шульженко). Дослідження учених довели, що корекційно-розвиткові заняття 3 дітьми означеної категорії мають ґрунтуватися на індивідуальному та диференційованому підходах, щоб забезпечити оптимальний розвиток особистості. Заняття необхідно спрямовувати на стимулювання пізнавальної активності дітей з розладами аутистичного спектру, що реалізується через стимулювання мотивації дітей до пізнання нового. Важливе значення має й створене культурно-освітнє середовище, в якому перебуває дитина з розладами аутистичного спектру. Від організації середовища залежить і поведінка дітей, і їх активність у спілкуванні.

Стурбованість вітчизняних вчених щодо проблеми аутизму й аутистичних порушень в Україні можна спостерігати, аналізуючи зміст словників та українських наукових видань. Зокрема, у дефектологічному словнику за редакцією В. Бондаря, В. Синьова (2011р.) розкриття поняття аутизму і аутистичних порушень значно розширюється. Аутизм - важке порушення розвитку, що характеризується значними недоліками у фрормуванні соціальних і комунікативних зв'язків із реальністю; виявляється в зосередженості на власних переживаннях, обмеженні спілкування з іншими людьми, а також проявами стереотипних інтересів [1, с. 89].

Аутичний розлад - це важка фрорма патології психічного розвитку з соціальними, комунікативними, мовленнєвими, регуляторними порушеннями [1, с. 57].

Спектр аутистичних порушень - це багатоманітний різновид, відмінностей, відхилень і порушень, центральним і спільним для яких є порушення соціальної інтеграції та небажання (навіть острах) аутистичних людей вступати в будь-який контакт із суспільством, зокрема зі своїм оточенням [4, с. 7-8].

Серед методів впливу на поведінку та розвиток дітей з аутистичними порушеннями в останні десятиліття активно вивчають музикотерапію. Перша книга «Музична терапія для дітей з аутизмом» була опублікована Juliette Alvin у 1978 році. У книзі описується вплив музики на розвиток дитини 3 аутизмом, доробки автора актуальні й сьогодні.

M. Boso (1984) досліджував вплив музикотерапії на поведінку підлітків з вираженим аутизмом і дійшов висновків, що музикотерапія допомогла зменшити прояви у них аутистичних рис. Для розвитку мовленнєвої діяльності дітей 3 аутистичними проявами W. Prevezer (2002) застосовувала музичну терапію, S.M.K. Brown (2017) наголошував, що участь у сеансах музикотерапії дозволяє людині 3 аутизмом відчувати і розуміти більш широкий діапазон емоцій. Учений A. Woodward (2019) помічав, що музикотерапія все частіше використовується як частина інтервенційних програм для дітей з аутизмом та їхніх батьків, оскільки стимулює ранню емоційну взаємодію між матір'ю і дитиною, що надалі веде до нормального розвитку соціальних навичок у дітей з розладами аутистичного спектру.

Виділення не вирішених раніше частин загальної проблеми. Попри значну кількість досліджень розвитку дітей 3 розладами аутистичного спектру, бракує опису методів впливу на поведінку таких дітей дошкільного віку в умовах закладів дошкільної освіти, зокрема музикотерапії. Це зумовило вибір теми дослідження.

Мета статті - вивчення впливу музичних творів, музикотерапії на поведінку дітей дошкільного віку з розладами аутистичного спектру.

Виклад основного матеріалу. Важливе значення для дитини з порушенням відіграє виховний процес, який спрямований на фрормування адаптивних якостей, які допоможуть у самоконтролі поведінки таких дітей.

Відомо, що інтелектуальний розвиток дітей 3 розладами аутистичного спектру може бути різним: як збереженим, так і порушеним. Однак серед особливостей їх розвитку можна виокремити порушення психомоторного розвитку [2, с. 192]. Серед особливостей також виділяють рухову активність, яка не має певної мети, стереотипні рухи. Причому рухова активність часто змінюється на рухову пасивність, коли дитина не лише уповільнює рухи, а припиняє їх, начебто «завмирає».

У дітей 3 розладами аутистичного спектру також фріксуються порушення й особливості поведінки, серед яких типовими є довільні рухи, які заважають оволодіти навичками самообслуговування. Мозкова гіпотонія виявляється у своєрідності рухів, їх непередбачуваності. Поведінка таких дітей може бути несподіваною і різною: без відомих причин спостерігаються незадоволення, агресія або навпаки «приплів» бурної радості. Такі особливості поведінки можна фріксувати вже у ранньому дитячому та дошкільному віці, що ускладнює соціалізацію дитини, її перебування у закладі дошкільної освіти.

3 огляду на вищевикладене актуалізується пошук ученими (К. Островська, Д. Шульженко, Г. Хворова) методів корекції особливостей поведінки дітей з розладами аутистичного спектру, серед яких розглядається й музикотерапія.

В останні десятиліття терапія музикою набуває популярності. Завдяки музиці вивчено особливості розвитку особистості загалом й осіб з аутизмом зокрема.

Музичні твори можуть як підвищувати настрій, стимулювати почуття радості й рухову активність, так й навпаки, гальмувати стереотипні рухи в осіб 
3 аутизмом, знижувати гіпертонус м'язів. Дітям дошкільного віку з розладами аутистичного спектру правильно сплановані сеанси музикотерапії та музичні заняття прищеплюють не лише інтерес до музики, але й розширюють уявлення про оточуюче середовище, розвивають уяву, навчають слухати. Для того щоб музика мала терапевтичний вплив на дитину з розладами аутистичного спектру, необхідно вивчати її індивідуальні особливості. Вчені зазначають, що музика може бути провідним методом корекції поведінкових порушень у дошкільників 3 розладами аутистичного спектру лише в тому разі, коли музичний вплив $€$ системним і різноплановим та включає співи пісень, звуків (вокалотерапію), ритмічні рухи під правильно дібрану музику (танці, наприклад), гру на музичних інструментах тощо [3]. Особливої популярності набули у практиці застосування ритмічних звуків під музику, які, за спостереженнями, позитивно впливають за розвиток вольових якостей дітей.

Узгодженість рухів, які передбачені у музичних заняттях 3 дітьми 3 розладами аутистичного спектру, стимулює у дітей позитивні емоції, гарний настрій, діти навчаються взаємодіяти у колективі. Підтримка, заохочення з боку фрахівців розвивають у дітей з розладами аутистичного спектру впевненість, викликають задоволення від перебування з однолітками. У закладі дошкільної освіти, де активно проводять музичні заняття 3 дітьми 3 аутистичними порушеннями, фріксують інтерес у них до різних музичних інструментів, дітям подобається самім визивати звучання доступних їм музичних інструментів. 3 часом хаотичне стукання по музичних інструментах змінюється бажанням слухати їх гармонійне звучання, отже діти починають слухати і розуміти музику. Діти із задоволенням оволодівають елементарними навичками «гри» на доступних і простих музичних інструментах, що стимулює як їх загальний психомоторний розвиток, так і емоційно-вольову сфреру.

P. Призванська, Д. Шульженко пропонують для занять добирати мелодії народних танців, які звучать у записі або виконуються на фортепіано. Танці слід вибирати такі, що стимулюють дітей, але не збуджують занадто сильно та мають прийнятний темп та ритм у дві восьмих і одну четвертну ноти. На початку діти вчаться зупинятися і замовкати, коли припиняється музика, і починати рух знову, коли музика знову зазвучить [3].

У музично-ритмічній діяльності основою $\epsilon$ музично-ритмічні рухи дітей дошкільних закладів: плескання у долоні; помахування кистями рук; повороти кистями рук («веселі ручки»); пружинисте напівприсідання; перекачування 3 ноги на ногу; притупування однією ногою; поперемінне притупування ногами; поперемінне виставляння ноги на носочок; плескання в долоні і по колінах.
Це приблизний перелік музично-ритмічних рухів, адже діти з розладами аутистичного спектру бувають непередбачуваними. Слід бути готовим до того, що вони приймають або не приймають наші пропозиції. У разі неприйняття треба швидко перелаштуватися на інший вид музичної діяльності [3].

На заняттях (сеансах) 3 музикотерапії діти слухають різні музичні твори: як дитячу музику, дитячі пісні (сучасні та зі старих мультиплікаційних фрільмів), так і українську народну музику та пісні, а також твори класичної музики. По-перше, це сприяє фрормуванню естетичного смаку, а по-друге, різна музика корегує прояви негативізму у дітей, підвищує настрій, викликає посмішку або заспокоює. Залежно від музики дітям стає доступною не лише веселка емоцій, але й опанування власними емоціями через взаємодію з фахівцем та однолітками. Важливим у проведенні музикотерапії $€$, як ми вже зазначали, систематичність занять. Для цього доцільно залучати батьків, знайомити їх з основами музикотерапії, надавати необхідну інфрормацію і літературу. Важливою допомогою 3 боку батьків дітей з розладами аутистичного спектру буде спостереження за поведінкою дитини як після музичного сеансу у дошкільному закладі, так і вдома, під час та після прослуховування дитиною музичної добірки, яку рекомендує фрахівець. Також доцільно залучати батьків для обговорення змісту сеансів музичної терапії, заздалегідь знайомити їх як з метою, так і змістом музичних сеансів.

Сумісне 3 батьками музикування, прослуховування пісень, творів сприятиме зміцненню у дитини емоційного зв'язку з ними, гармонізації стосунків між усіма членами родини. Співробітництво 3 батьками дітей з особливими освітніми потребами, зокрема 3 розладами аутистичного спектру має не лише інформативний складник, але й мотиваційний, який полягає в тому, що сумісний пошук музичних творів, прослуховування музики 3 дітьми стимулюють батьків таких дітей до активної взаємодії як з фахівцем, так і власною дитино. Узгоджена дія батьків під час реалізації музикотерапії вдома спрямовані на стимулювання сумісних з дітьми емоцій.

Дітям старшого дошкільного віку з розладами аутистичного спектру в умовах ЗДО № 33 комбінованого типу м. Харкова на заняттях із музикотерапії пропонуються музичні твори у поєднанні 3 наочним, ігровим матеріалом для сенсорного розвитку. Наприклад, є різні іграшки. Перед дітьми ставляться завдання різної складності, залежно від віку та індивідуально-психологічних особливостей. Зокрема, ставиться завдання не лише розрізняти контрастні звучання, а й відтворювати їх. Наприклад, у грі «Звуки тварин» дитині пропонується показати, як нявкає кішка (низький звук) або кошеня (високий звук). Відповідно до поставлених завдань фрахівцем добирається і репер- 
туар. На перших етапах музичної терапії твори $€$ нескладними, зрозумілими для дитини, із залученням наочності. Наприклад, якщо це пісенька про собачку, то демонструється м'яка іграшкасобачка, відповідно до змісту пісень й інші іграшкитваринки. Якщо це пісні про явища природи, пори року, то також доцільно застосування наочності, а саме демонстрування малюнків, відео про природу, про яку співається. Народні пісні, народну музику рекомендовано супроводжувати наочним показом українського побуту або одягу, про який йдеться у пісні.

Таким чином, вищевикладене доводить, що застосування наочності підвищує ефективність музикотерапії з дітьми з розладами аутистичного спектру. Демонстрація наочного матеріалу дитині стимулює як зорове сприйняття, так і пам'ять. Дефектологи можуть застосовувати ляльковий театр, пальчикові ляльки, щоб дитині став зміст пісні зрозумілішим. Ураховуючи те, що провідною діяльністю дошкільника є гра, ігрова музикотерапія для них є цікавою, діти із задоволенням перебувають на занятті.

Музикотерапія у закладі дошкільної освіти може проводитися в індивідуальній, малогруповій та груповій фрормах (до 8 осіб).

Для зменшення проявів агресивної поведінки у ЗДО № 33 комбінованого типу м. Харкова дітям пропонують також музику з переходом до заспокійливої, як-от: В. Моцарт «Соната для фрортепіано», II частина, фра-мажор (Adagio) та Дивертисмент, ре-мажор (Andante); Ж. Масне, «Роздум»; А. Дворжак «Симфонія № 8 (Соль-мажор)», II частина (Adagio); Й. Штраус «Повільний вальс»; Ф. Шуберт, «Вечірня серенада»; А. Вівальді «Концерт для фрлейти 3 оркестром № 4»; П. Чайковський «Пори року», «Баркарола»; К. Сен-Санс «Лебідь» [3].

Для релаксації та заспокоєння рекомендовано таку музику: В. Моцарт, «Ближче до мрії»; Л. Бетховен «Елізі»; Й. Бах « Брандербурзький концерт N 2 (Andante)»; Т. Альбіноні, Адажіо; М. Брух «Скрипічний концерт N 1» (Adagio); С. Рахманінов «Рапсодія на тему Паганіні»; М. Лисенко «Елегія» [3].
Для активізації та настроєвої стимуляції можна використовувати такі твори: В. Моцарта-увертюри до опер «Чарівна фрлейта» та «Весілля Фігаро», Маленьку нічну серенаду (Allegro), Е. Гріг - Сюїта «Пер Ґюнт» («Ранок»), П. Чайковський - увертюра до балету «Лускунчик»; М. Лисенко - «Українська рапсодія»; М. Скорик «Мелодія» [3].

Висновки. Підсумовуючи, зазначимо, що корекційно-розвиткова робота 3 дошкільниками 3 розладами аутистичного спектру $€$ багатоаспектною та має різні методи і методики, серед яких виділено музикотерапію, яка сприяє активізації пізнавальної й розумової діяльності, стимулює різні почуття, залежно від творів, які пропонуються дітям для прослуховування. Відповідно до почуттів, які необхідно стимулювати у дитини, враховуючи індивідуально-психологічні особливості, було розроблено тематичні сенси музикотерапії, що складаються з сучасних музичних творів та спрямовані на гармонізацію міжособистісних стосунків, корекцію поведінкових порушень, фрормування позитивних відчуттів, та дібрано класичні музичні твори за такими напрямами: підвищення настрою, стимулювання почуття радості, зменшення агресивності, зменшення почуття страху. Зазначимо, що музикотерапія проводилася у малогруповій та груповій формах. Перспективою подальшого дослідження $€$ розробка і впровадження комплексної програми музикотерапії для дошкільників з розладами аутистичного спектру та аналіз її ефективності.

\section{БІБЛІОГРАФІЧНИЙ СПИСОК:}

1. Дефектологічний словник: навчальний посібник / За редакцією В.І. Бондаря, В.М. Синьова. Київ : «МП Леся», 2011. 528 с.

2. Колишкін О.В. Вступ до спеціальності «Корекційна освіта»: навч. посіб. Суми : Університетська книга, 2014. 392 с.

3. Призванська Р.А., Шульженко Д.І. Музична терапія для дітей з аутизмом : [навч. посіб.]. Львів : Видавничий центр ЛнУ імені Івана Франка, 2020. 75 с

4. Шульженко Д.І. Основи психологічної корекції аутистичних порушень у дітей : монограсрія Київ : Д.М. Кейдун, 2009. 385с. 